\title{
Technology Of Forming A Multicomponent Organizational Structure Of A Continuous Pedagogical Education System
}

\section{Tecnología para formar una estructura organizativa multicomponente de un sistema de educación pedagógica continua}

\author{
Marina Georgiyevna Sergeeva \\ Research Institute of the Federal Penitentiary Service of Russia, Moscow, Russia \\ ORCID: https://orcid.org/0000-0001-8365-6088 \\ Aleksandra Sergeevna Sokolova \\ Moscow State Linguistic University, Moscow, Russia \\ ORCID: https://orcid.org/0000-0002-2663-5421 \\ Lyudmila Zhalalovna Karavanova \\ Peoples' Friendship University of Russia, Moscow, Russia \\ Tver State University, Tver, Russia \\ ORCID: https://orcid.org/0000-0003-0861-5109 \\ Elena Vladimirovna Skudnyakova
}

K.G. Razumovsky Moscow State University of Technologies and Management (the First

Cossack University), Moscow, Russia

ORCID: https://orcid.org/0000-0002-6975-1852

Elena Nikolaevna Ishchenko

Bauman Moscow State Technical University (National Research University), Moscow, Russia

ORCID: https://orcid.org/0000-0002-6691-4994

Received 09-08-20 Revised 10-10-20

*Correspondence

Email: sergeeva198262@mail.ru
Accepted 20-12-21 On line 02-12-21

Cite as:

\footnotetext{
Georgiyevna, M., Sergeevna, A., Zhalalovna, L., Vladimirovna, E. \& Nikolaevna, E. (2021). Technology Of Forming A Multicomponent Organizational Structure Of A Continuous Pedagogical Education System. Propósitos y Representaciones, 9(SPE2), e991. Doi: http://dx.doi.org/10.20511/pyr2021.v9nSPE2.991
} 


\section{Summary}

Successful results of all types of professional activities largely depend on the quality of training. At present, however, the acquired knowledge does not guarantee a university graduate stability of success throughout his/her career. Thus, the concept of lifelong education was gradually formed. From the previously established stereotype "education for life", society is moving to the "education throughout life". The traditional division of a person's active life into the period of professional activity and study is blurring. There is a need for a transition to continuing professional education throughout life. One of the most important tasks for the management is to ensure the continuous development and survival of the organizations. Such a task is also vital for the institutions of additional professional education. With the transition to the newly established market relations, in the Russian Federation, the conditions for the operation of the system of additional professional education have changed significantly. First of all, a market for services in the field of additional professional education has emerged, where a large number of organizations of various forms of ownership operate, creating strong competition. In these conditions, the maximum consideration of different factors influencing on the additional professional education institutions, as well as the choice of a management strategy, is an important condition for their successful development and competitiveness. The demand of society for an effective system of additional vocational education determines its place and role in the state policy in relation to the development of human resources. At the same time, it is necessary to take into account the challenges of the labor market, the increasing needs of production, the real sector of the economy, the non-production sphere in qualified workers, specialists, managers, as well as training and re-training of unemployed citizens.

Keywords: lifelong education, pedagogical training, vocational training, additional professional education.

\section{Resumen}

Los resultados satisfactorios de todo tipo de actividades profesionales dependen en gran medida de la calidad de la formación. En la actualidad, sin embargo, los conocimientos adquiridos no garantizan la estabilidad del éxito de un egresado universitario a lo largo de su carrera. Así, se fue formando gradualmente el concepto de educación permanente. Del estereotipo previamente establecido de "educación para la vida", la sociedad pasa a la "educación para toda la vida". La división tradicional de la vida activa de una persona en el período de actividad profesional y estudio se está difuminando. Existe la necesidad de una transición a la educación profesional continua durante toda la vida. Una de las tareas más importantes para la gestión es asegurar el desarrollo continuo y la supervivencia de las organizaciones. Esta tarea también es vital para las instituciones de educación profesional adicional. Con la transición a las relaciones de mercado recientemente establecidas, en la Federación de Rusia, las condiciones para el funcionamiento del sistema de educación profesional adicional han cambiado significativamente. En primer lugar, ha surgido un mercado de servicios en el campo de la educación profesional adicional, donde operan un gran número de organizaciones de diversas formas de propiedad, creando una fuerte competencia. En estas condiciones, la máxima consideración de los diferentes factores que influyen en las instituciones de educación profesional adicionales, así como la elección de una estrategia de gestión, es una condición importante para su exitoso desarrollo y competitividad. La demanda de la sociedad de un sistema eficaz de formación profesional adicional determina su lugar y papel en la política estatal en relación con el desarrollo de los recursos humanos. Al mismo tiempo, es necesario tener en cuenta los desafíos del mercado laboral, las crecientes necesidades de la producción, el sector real de la economía, el ámbito no productivo en trabajadores calificados, especialistas, gerentes, así como la formación y reentrenamiento de ciudadanos desempleados.

Palabras clave: educación permanente, formación pedagógica, formación profesional, formación profesional adicional. 


\section{Introducción}

The Russian market for additional professional education services began to form in the 1990s. During this period, the first non-state educational institutions were formed, which provided educational services on a commercial basis: various training centers, business schools, educational associations, etc. The market of additional professional education is still in the process of development. The additional professional education system, in contrast to general education in institutions of primary, secondary and higher education, adequately and quickly responds to changes in the labor market. The distinctive feature of advanced training programs is their short-term duration, focus on a specific customer and readiness to respond to market requirements (Gurevich, 2019). According to modern estimates, intensive technological development doubles the total amount of information every five years, updating 5 percent of theoretical and 20 percent of practical knowledge annually (Dolzhich, Dmitrichenkova, 2018). In these conditions, continuing education and additional professional education as its integral part contribute to the growth of demand for a highly-qualified specialist and the development of professional culture.

Thus, additional professional education acts as one of the most effective ways to implement the principle of continuity. The relevance of this study is due to the development of additional professional education institutions in the current system of continuous education.

It is important to note that additional professional education provides an opportunity to acquire the necessary competencies in a timely and flexible manner. Therefore, there are positive trends on the market for the provision of educational services in the field of additional professional education. In order for the supply to match the demand, it is necessary to expeditiously assess and forecast the needs of employees and employers.

The consumers of educational services of additional professional education is both each individual employee and employers who are interested in staff training and retraining.

As part of the analysis of the population's need for additional professional education, we used the data from surveys monitoring the education economy conducted by the National Research University "Higher School of Economics" (Moscow).

According to the results of surveys, people aged 31 to 45 (38.8\%) and over 45 (32.6\%) develop their professional knowledge and skills most actively. The share of young people (under 25) involved in this process is significantly lower (9.7\%) (Kuznetsov, 2019).

The retraining of specialists with higher education who received the qualification a long time ago and therefore ceased to be in demand in the labor market is relevant. In the 1990s, the main consumers of such training were engineering and technical workers of the Soviet period, as well as military officers who were discharged to the reserve or retired. Nowadays specialists in the humanities who were educated in the 1990s and later prevail. The upgrading programs are in high demand by managers holding high positions in various industries, aimed at deepening knowledge and developing various skills (Bermus, 2020).

Thus, the maximum coverage of the adult population with additional or further education in the Russian Federation is achieved at the age of 25-49, after 50 there is a sharp decline. The level of coverage of the population with further education remains quite low about $17-20 \%$ of the working population aged 25-64. This is 2 times lower than in the countries of the European Union (40.2\%), and almost 3 times lower than in the countries of the Organization for Economic Cooperation and Development (52\%) (Bayborodova, 2019).

The main prerequisites for the transition to lifelong education and continuous generation of new knowledge in the modern world are as follows (Wang et al., 2018): 
1) rapid obsolescence of knowledge, skills and abilities, which need to be updated every few years;

2) changes in the sphere of labor and employment, requiring employees to periodically change their occupation and retrain accordingly.

The modernization of socio-economic systems sets new requirements for professional activity, which leads to the necessity to constantly update the accumulated knowledge, professional skills and abilities. The need for additional professional education is growing in the priority and growth branches of the economy. The main motivation for obtaining additional professional education is the desire to strengthen the position in the workplace. Low competition in the labor market reduces incentives for obtaining additional professional education.

Based on the assessment of the needs of the population, we can conclude that the demand for training in additional education programs is increasing. To keep this trend, Russian companies tend to focus on foreign experience in managing the additional professional education system.

\section{Literature review}

In the educational theory and practice of Western countries, a significant number of scientists and researchers underlined the constant nature of the educational process that accompanies all human life. Many foreign scientists and philosophers (E. Faure, J. Bowen, P. Jarvis, D.E. Durkheim, J. Field, P. Hobson, R. Pierce, C. Rogers, John Dewey and others) believed that education has no boundaries and is continuous, changing process of reconstruction, transformation and development in accordance with the changes taking place in society (Bírová et al., 2018; Volkova, Panchenko, 2018; Blinova, Dugina, Zabolotskikh, 2018; Blinov, 2019).

The theory of Western additional professional education or further education is based on the following concepts: lifelong learning (Robert Pierce), continuous education (John Dewey), adult education, continuing education (F. Thomas, Torsten Husen), recurrent education, which includes nine principles of educational systems in the future: adaptability, context, diversity, efficiency, equality, participation, personalization, quality, unity (Drozd, 2019).

The broad interpretation of the term "lifelong education" coincides with the definition adopted in Russia, despite the fact that the term appeared much later in this country. Lifelong education represents the educational system as a whole, which contains various forms of education: formal, informal, non-formal, as well as the integration and clear division of these levels and forms of education horizontally and vertically.

The Higher School of Economics (Moscow) conducted a special survey of the population's engagement in further education. As a result, the main indicators of the participation of the adult population of Russia in lifelong education were obtained. Figure 1 shows the survey data, comparable to foreign estimates (Surtaeva, 2019). 


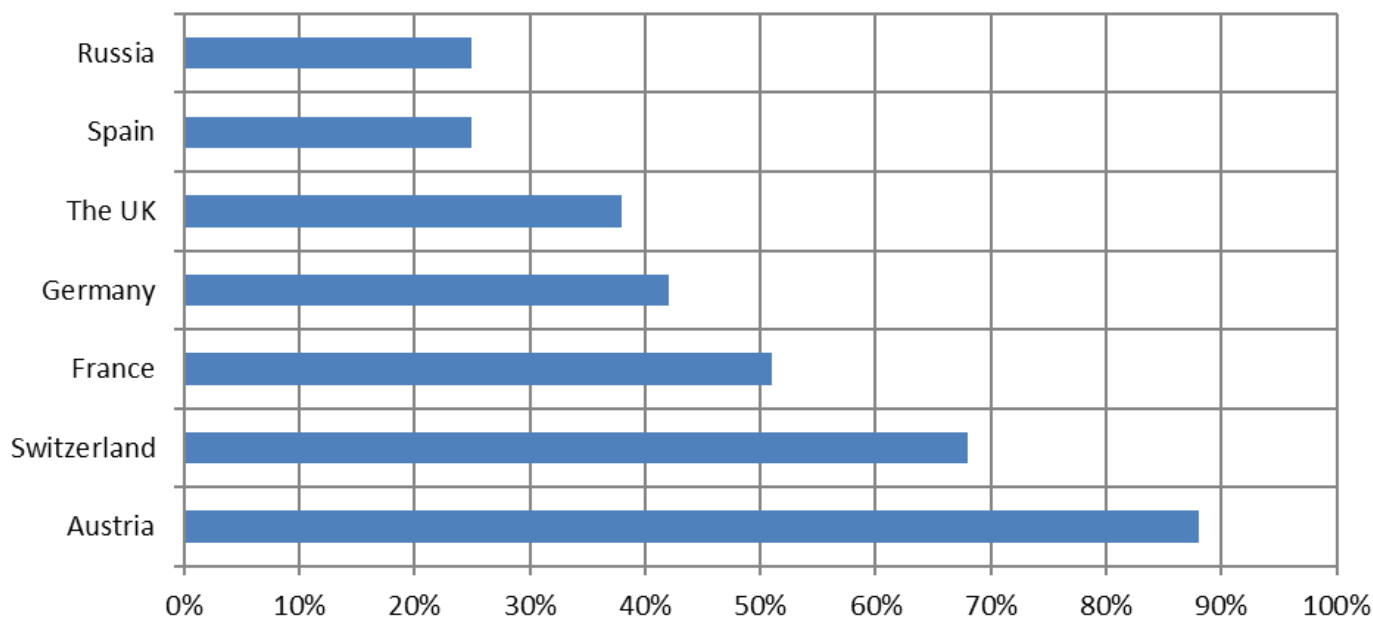

(Figure 1): Participation of the adult population in lifelong education (countries, \%)

Figure 1 shows that Russia is far from being a leader. The population participation rate was $25 \%$, whereas in Austria 89\%, Switzerland 68\%, France 51\%, Germany 42\%, Great Britain $38 \%$, Spain 25\% (Patrusheva, 2019). Based on this assessment, it would be useful to consider the systems and forms of additional professional education that are successfully operating abroad.

The educational system of Austria, as well as in Russia, is subject not only to the general European laws, but also to the traditional Austrian ones, which have been effectively functioning for more than 50 years. Effectiveness is demonstrated by the lowest youth unemployment rate in Europe, the lowest dropout rate before graduation. Almost everyone who graduates from an educational institution and successfully gets a degree works by profession (Neverkovich et al., 2018).

The educational structure of Austria and the fact that a large part of the population prefers vocational training to general education determines the need for a large number of professional development courses, as well as for the high quality of these courses. The Austrian education system is characterized by a variety of public and commercial institutions offering continuing education courses.

The largest organizations in Austria providing professional development courses are (Gorev et al., 2018):

1) IBW with the focus on application-oriented research issues and topics with relevance for the world of business;

2) WIFI - Institute for Economic Development;

3) Quality Austria - training and certification of personnel. Quality Austria has been operating as a training organization in Austria since the 1960s. It currently offers over 60 different courses. The organization is accredited for the personnel certification in accordance with international standards. From 7000 to 7500 people study at the courses annually.

The main features of the Swiss education system are diversity, wide freedom of choice and flexibility. There are various educational or training opportunities and access to different types of curricula and schools in Switzerland (Burina, 2015). 
The Swiss government is responsible for education at the cantonal and federal level. Compulsory education is funded and administered by local municipalities and cantons. In postcompulsory education, the federal authorities and the cantons share their responsibilities.

A student aged 15-16 after completing compulsory education can apply for an apprenticeship. Two thirds of young people in Switzerland use this form of education. It combines a part-time class in a vocational school with an apprenticeship (in-service training) at a training company. This form of complete secondary education is called dual vocational education and training (VET) or apprenticeship. Its duration is about 3-4 years and it provides students with the opportunity to gain theoretical knowledge and at the same time practical skills. Many specialties in Switzerland can be obtained at the stage of complete secondary education, while in other countries such professions are taught at the higher level of education (Sergeeva et al., 2018).

Switzerland's highly developed VET system has many strengths. Schools of vocational education train young professionals who acquire theoretical anf practical knowledge in a specific field. The two-channel education system contributes to the emergence of young workers with practical skills who are able to perform tasks, solving the various needs of the economy. It also helps to reduce youth unemployment in Switzerland.

Lifelong learning is an integral part of personal development. This is the reason why most people in Switzerland take continuing education and training courses.

Each country has specific features of the content and organization of professional education. There are also common features. Professional education abroad is aimed at training not a narrow specialist, but in a specific area. It is also closely related to general education and is oriented towards continuity. Professional education is flexible and integrated with production.

The professional education and training system, which plays the role of initial vocational training, is developed at a high level. It includes public and private professional education organizations, centralized and decentralized systems. It should be noted that the forms of organization of additional professional education systems in each country are different and it is impossible to single out the system of training and retraining of personnel, which is the best.

\section{Proposed methodology}

The constant updating of technologies makes fundamentally new professional requirements for training in the market of educational services, which, in turn, is viewed as a continuous process that ensures the exchange and constant updating of knowledge. On the other hand, consumers of educational services put forward demands for mobility, accessibility and flexibility of the learning process, as well as the diversity and relevance of content.

One of the directions for improving and developing the additional professional education is the introduction of new educational technologies and principles, ensuring the effective implementation of new models and contents of continuous education, including modern information and communication technologies (Utemov et al., 2018).

The image and competitiveness of an educational institution is increasing due to a more complete satisfaction of the requirements of consumers, an expansion of the geographic coverage of students and an increase in the variety of training programs based on distance learning technologies.

One of the new developments in education, driven by the digital society, is the widespread adoption of massive open online courses (MOOCs). 
MOOC is an online course with interactive participation and open access, one of the most effective forms of the implementation of distance learning technologies.

Massive open online courses (MOOCs) offer accessible and affordable remote learning opportunities to students all over the world. MOOCs are presented in the form of electronic online courses, educational and methodological complexes, which include text lecture notes, video lectures, pre-recorded lectures and webinars, home assignments, midterm tests and final exams. The authors of the courses are teachers of educational institutions.

Abroad, massive online courses have long become a trend. MOOCs are gradually replacing full-time education.

Many famous higher education institutions of the USA and Europe, including Harvard University and the Massachusetts Institute of Technology, deliver the online courses on a variety of topics and educational levels (Sharonova, Trubnikova, Sokolova, 2018).

MOOCs are currently actively used in the educational process for various purposes: as a new form of distance learning, for integration into full-time study programs in various subject areas or integration with programs of additional professional education, including advanced training of research and teaching staff (Esekeshova, Sagalieva, 2018).

Experts included massive open online courses among the most promising trends in the development of the educational sphere until 2028, which reveal new opportunities in the field of distance education. MOOCs are global in nature, as they remove time and territorial barriers, increase the level of independence and motivation of students in acquiring professional skills in a global digital world.

MOOCs are focused on active participation and interaction of students with each other and with teachers. Another important characteristic is that each student has a personal learning environment. The number of students registered for various MOOCs varies from several hundred to tens and hundreds of thousands. Upon completion of the online course, it is possible to obtain an official certificate.

\section{Result Analysis}

According to the platform developers, since their inception, MOOCs collected a large number of positive reviews and reached a multimillion audience from all over the world. In 2017, the number of users was about 11 million people, with an average age of 35 years (Blinov, 2019).

Among the MOOC platforms, Coursera is the most in demand today.

Coursera was founded in 2012 by two Stanford professors and is one of the largest massive open access course providers in the world. According to the platform data, Russia is in the top 10 countries in which there is the highest interest of residents in online learning. Over the past 5 years, more than 23 million people signed up for training through this platform. The Coursera platform is a portal for building educational networks and learning.

At the moment, Coursera offers over 1,500 courses, 860 of them are free. 161 partners work with the resource, of which 149 are represented by educational organizations from 29 countries of the world, and Russia is one of them. At the 
beginning of 2018, several leading Russian educational organizations were located on the Coursera platform, among them:

- $\quad$ Moscow Institute of Physics and Technology;

- $\quad$ Saint Petersburg State University;

- $\quad$ Peter the Great St. Petersburg Polytechnic University;

- $\quad$ National Research Tomsk State University;

- $\quad$ National Research Nuclear University "MEPhI”;

- $\quad$ National Research University - Higher School of Economics (HSE);

- $\quad$ Novosibirsk State University (NSU).

One of the drawbacks of working with this platform is the lack of a Russianlanguage version, therefore, for users who do not speak English, it becomes difficult to understand the information provided (enrollment for a course, tuition fees, obtaining a certificate and other options).

$\mathrm{EdX}$ is another leading MOOC platform with about 10 million registered users. Leading platforms also include FutureLearn, XuetangX and Udacity (Bayborodova, 2019). Of the five largest providers, the only non-English platform is XuetangX, China (Figure 2).

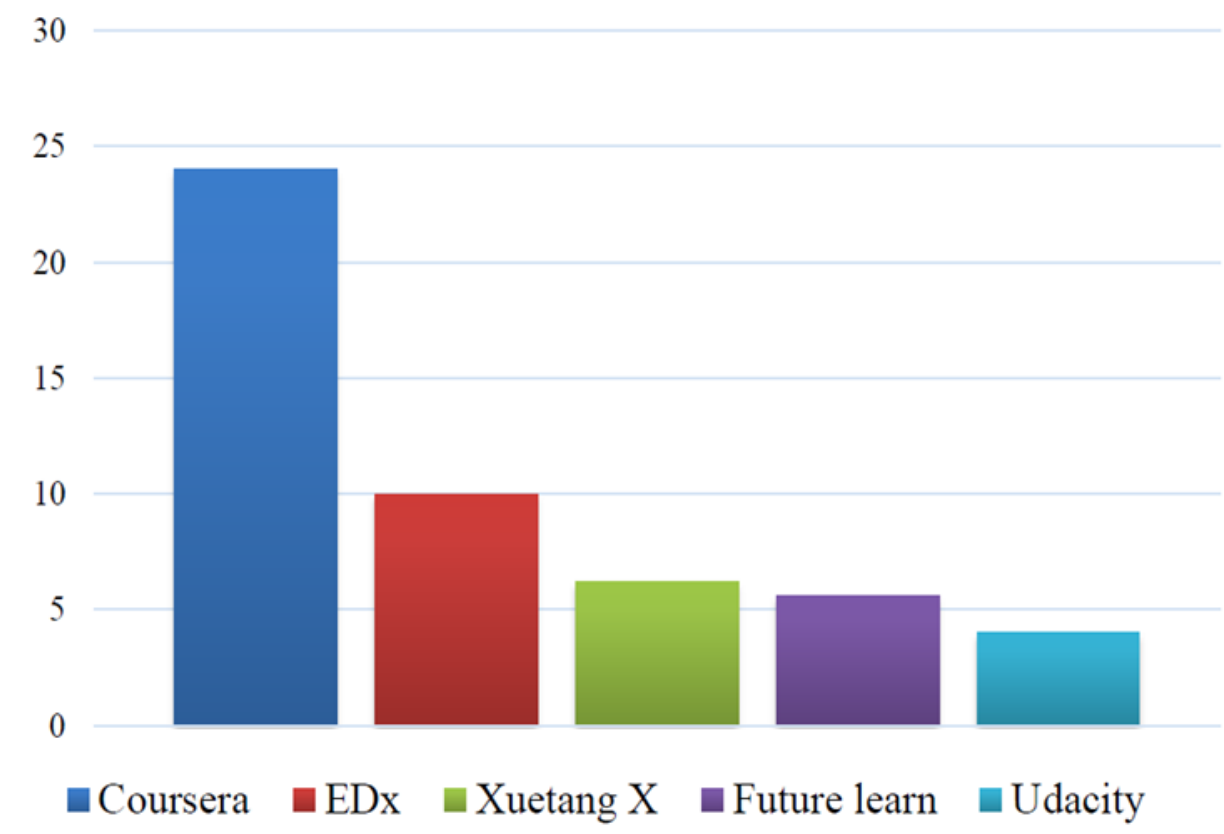

(Figure 2): Top MOOC providers by the number of registrations, million people

In 2016, more than 2,600 new courses were developed, whereas in 2015 the number of courses was 1,800. By 2017, the total number of MOOC courses reached 
6,850 (Figure 3). They are represented by over 700 universities. This number includes the University of Oxford.

\section{Growth of MOOCs}

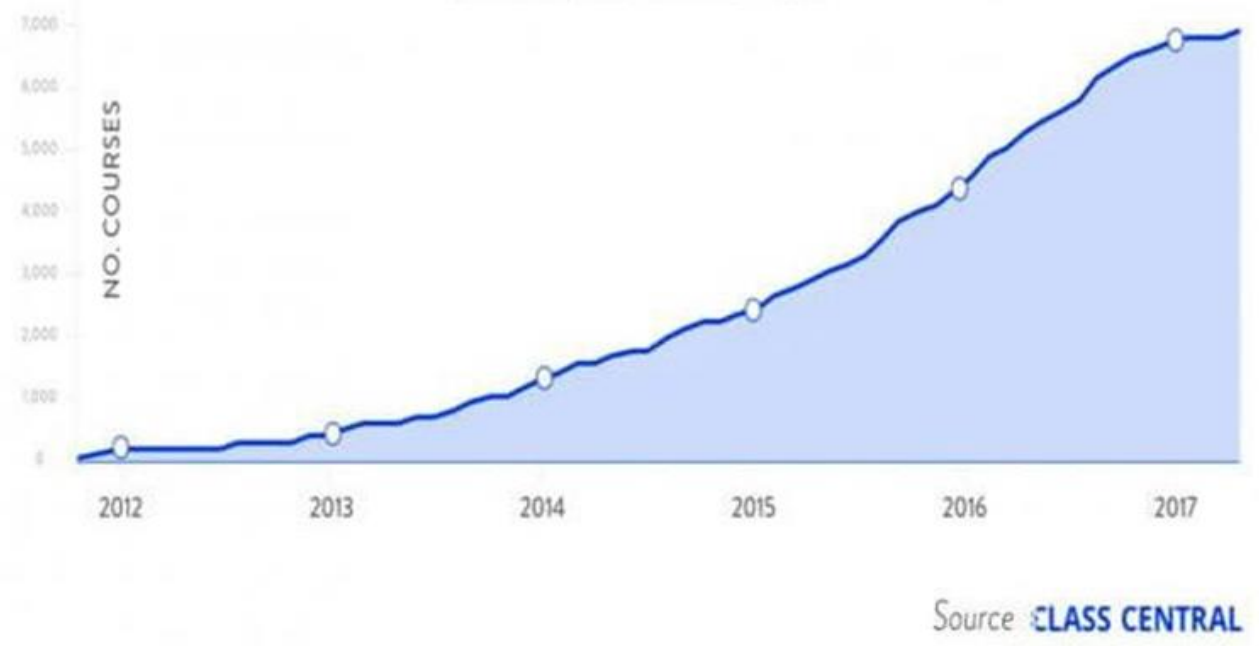

(Figure 3): Growth rates in the MOOC system, units

The structure of areas of study is shown in Figure 4. In 2018, more training programs related to the development of the most demanded skills in business and technology were offered (Gurevich, 2019).

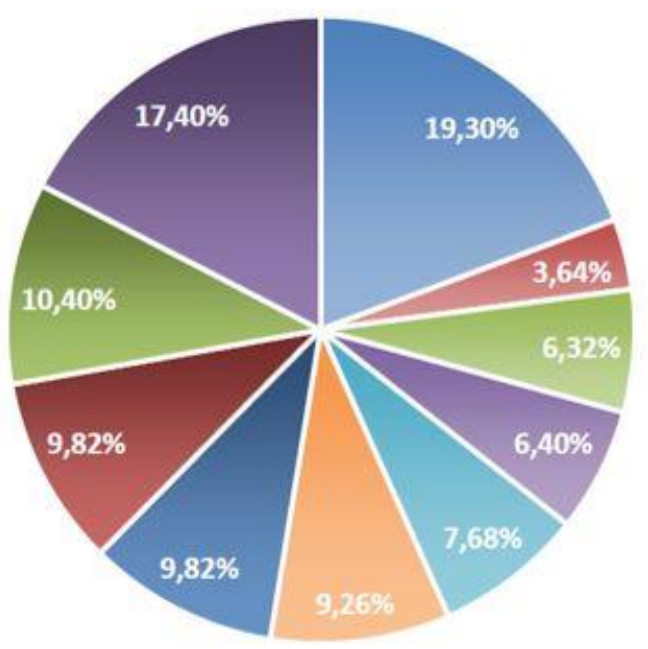

" Business and Management

" Mathematics

" Engineering and Technology

\# Art and Design

" Nursing and Healthcare

- Education and Teaching

(Figure 4): Distribution of courses by areas of study, \%

In Russia, the widespread use of MOOCs began at the end of 2013, the greatest activity was observed in 2014-2015. Currently, the Russian MOOC platforms include the following: Open Education, OpenProfession, Education in Russian; Stepic, Universarium, Lectorium, GeekBrains, University without Borders, Open Polytech, Netology, SDO LAN, NCEO and others.

\section{Conclusion}


According to analysts, the number of Russian online courses is growing rapidly. In order for students to have the opportunity to use a variety of courses, compare and choose the most suitable and interesting educational programs, the national project "Modern digital educational environment of the Russian Federation" was launched. It brings together many educational platforms and online courses, and also provides access to them on a one-stop basis. The catalog contains fairly complete and up-to-date information about all online courses. Automated exchange of information with educational platforms and information systems of educational institutions helps to timely learn about the availability of online courses for training or about any changes.

Thus, both abroad and in Russia, there is an increase in the number of participants in open online courses and, as a result, an increase in interest in this type of education. This is due to the fact that massive open online courses offer considerable scope for teaching people of different ages and location. Interest in MOOCs is also shown by educational institutions that strive to constantly develop their potential and use modern teaching methods to improve the effectiveness of their activities.

\section{Referencias}

Bayborodova, L.V. (2019). Pedagogy of additional education. Psychological and pedagogical support of children. Textbook for Academic Bachelor's Degree. Moscow: Yurayt Publishing House.

Bermus, A.G. (2020). Practical pedagogy: Textbook. Moscow: Yurayt Publishing House.

Bírová, J., Kružlík, P., Kalimullin, A., Sokolova, N., Haroun, Z., Králik, R., Vasbieva D. (2018). Mathematical and Statistical Bibliometric Indicators for Scholars in the Field of Romance Languages and Linguistics. EURASIA: Journal of Mathematics, Science and Technology Education, 14(12).

Blinov, V.I. (2019). Methods of vocational training: a textbook for secondary vocational education. Moscow: Yurayt Publishing House.

Blinova, S., Dugina, T., Zabolotskikh, A. (2018). Teaching mixed nationality groups (on the example of students from the Northern Caucasus region). INTED2018: Proceedings of the 12th International Technology, Education and Development Conference (pp. 79777982). Valencia, Spain.

Burina, E.V. (2015). The concept of an artificial language environment for teaching a second foreign language (on the example of the French language). Bulletin of the RUDN University. Series "Russian and foreign languages and methods of teaching", 3, 59-65.

Dolzhich, E., Dmitrichenkova, S. (2018). Computer science terminology (a case study of the Spanish language). INTED2018: Proceedings of the 12th International Technology, Education and Development Conference (pp. 2556-2559). Valencia, Spain.

Drozd, K.V. (2019). Actual problems of pedagogy and education. Textbook and workbook for academic bachelor's degree. Moscow: Yurayt Publishing House.

Esekeshova, M., Sagalieva, J. (2018). Pedagogy of higher education: textbook. Moscow: Foliant.

Gorev, P., Telegina, N., Karavanova, L., Feshina, S. (2018). Puzzles as a didactic tool for development of mathematical abilities of junior schoolchildren in basic and additional mathematical education. EURASIA: Journal of Mathematics, Science and Technology Education, 14 (10), pp. 178-185.

Gurevich, P.S. (2019). Psychology and pedagogy. Textbook and workbook for academic bachelor's degree. Moscow: Yurayt Publishing House.

Kuznetsov, V.V. (2019). General and professional pedagogy. Textbook and workbook for applied baccalaureate. Moscow: Yurayt Publishing House.

Neverkovich, S., Bubnova, I., Kosarenko, N., Sakhieva, R., Sizova, Zh., Zakharova, V., Sergeeva, M. (2018). Students' internet addiction: study and prevention. Eurasia Journal of Mathematics, Science and Technology Education, 14(4), 1483-1495.

Patrusheva, I.V. (2019). Psychology and pedagogy of the game. Textbook for vocational education. Moscow: Yurayt Publishing House. 
Sergeeva, M., Shumeyko, A., Serebrennikova, A., Denisov, A., Bondarenko, N., Getmanova, E. (2018). Innovative pedagogical experience in practice of modern education modernization. Modern Journal of Language Teaching Methods, 8(11), 814-823.

Sharonova, S., Trubnikova, N., Sokolova, N. (2018). Interpreting religious symbols as basic component of social value formation. European Journal of Science and Theology, 14(3), 117-129.

Surtaeva, N.N. (2019). Pedagogy, Pedagogical technologies: textbook for vocational education. Moscow: Yurayt Publishing House.

Utemov, V., Khusainova, R., Sergeeva, M., Shestak, V. (2018). Full Packaged Learning Solutions for Studying Mathematics at School. Eurasia Journal of Mathematics, Science and Technology Education, 14(12).

Volkova, Y., Panchenko, N. (2018). Discourse variation of the concepts of destructive emotions. Vestnik Rossiiskogo Universiteta Druzhby Narodov. Russian journal of linguistics, 22(1), 175-194.

Wang, S., Gorbunova, N., Masalimova, A., Bírová, J., Sergeeva, M. (2018). Formation of academic mobility of future foreign language teachers by means of media education technologies. Eurasia Journal of Mathematics, Science and Technology Education, 14(3), 959-976. 